\title{
Peningkatan Hasil Belajar Mekanika Teknik dengan Model Pembelajaran Ekspositori
}

\author{
Berowiyana \\ SMK Negeri 1 Blitar, Indonesia \\ Email: browiyana@gmail.com
}

\begin{tabular}{l}
\hline Tersedia Online di \\
\hline http://www.jurnal.unublitar.ac.id/i \\
ndex.php/briliant
\end{tabular}

Sejarah Artikel

Diterima pada 25 Oktober 2019

Disetujui pada 19 November 2019

Dipublikasikan pada 30

November 2019 Hal. 447-454

\section{Kata Kunci:}

Hasil Belajar, Mekanika Teknik, Ekspositori, Taktik

DOI:

http://dx.doi.org/10.28926/briliant. v3i4.377

\begin{abstract}
Abstrak: Prestasi belajar mekanika teknik siswa kelas X DPIB 1 SMK Negeri 1 Blitar ditunjukan nilai $\mathrm{P}$ dan $\mathrm{K}$ pada materi redoks yang belum mencapai batas ketuntasan secara klasikal sebesar $85 \%$. Hal ini terutama disebabkan karena model pembelajaran yang digunakan kurang sesuai. Tujuan penelitian ini untuk mendeskripsikan penerapan model pembelajaran ekspositori untuk meningkatkan hasil pembelajaran mekanika teknik siswa kelas X DPIB 1 SMK Negeri 1 Blitar. Hasil penelitian menunjukan bahwa tingkat ketuntasan awal pengetahuan dan keterampilan sebesar $44 \%$ dan $61 \%$. Dengan penerapan model pembelajaran ekspositori dan dengan taktik mengajar tertentu, tingkat ketuntasan meningkat menjadi $61 \%$ dan $78 \%$ (pada siklus 1) dan meningkat lagi menjadi 89\% dan 94\% (pada siklus 2), sehingga hasil belajar mekanika teknik pada bahasan konstruksi rangka batang kelas X DPIB 1 SMK Negeri 1 Blitar bisa mencapai ketuntasan belajar secara klasikal.
\end{abstract}

\section{PENDAHULUAN}

Sebagian besar kemampuan siswa pada pelajaran Mekanika Teknik ratarata kurang. Ini tampak dari nilai hasil ulangan selama semester 1 tahun pelajaran 2017/2018 (Data Guru). Proses pembelajaran dikatakan tuntas secara klasikal jika $85 \%$ dari jumlah siswa dalam satu kelas memperoleh nilai minimal sama dengan nilai KKM, yaitu 75 (tujuh puluh lima). Sehingga sebagian besar siswa untuk memperoleh nilai KKM perlu melalui serangkaian kegiatan remidi dan ujian ulang. Karena tuntutan materi pada silabus yang relatif banyak, berefek pada pengajaran di sekolah yang umumnya masih bersifat konvensional, maka guru kebanyakan juga berusaha menyampaikan materi ini kepada siswa sebanyak mungkin sesuai tuntutan silabus. Materi disampaikan dengan penjelasan dan siswa kebanyakan mendengarkan penjelasan guru, sambil mencatat seperlunya atau sesuai anjuran guru (Jumanta, 2014).

Dengan pembelajaran model ini, kebanyakan siswa kurang memahami materi yang disajikan guru. Terlebih lagi, karena pelajaran mekanika teknik ini memerlukan dasar pelajaran matematika dan fisika yang relatif cukup. Padahal, di sisi lain kebanyakan siswa kemampuan matematika dan fisikanya relatif kurang, misalnya untuk matapelajaran fisika, diharapkan siswa telah memahami besaran 
dan satuan serta konversinya, gaya dan keseimbangan. Sedangkan untuk pendukung matematika, diharapkan siswa telah menguasai bahasan persamaan linier satu variable maupun dua variable, bahasan trigonometri kususnya pada perhitungan sudut dan sisi segitiga menggunakan sinus, cosinus, dan tangen serta menggunakan dalil sinus maupun dalil cosinus. Karena ilmu pendukung ini kurang, maka pemahaman siswa pada pelajaran mekanika teknik rata-rata juga kurang. Pembelajaran seperti di atas kurang efektif, yang akan menyebabkan kejenuhan pada guru maupun siswanya dalam proses pembelajaran. Pengajaran dikatakan efektif jika penerima pesan dapat memahami makna yang dipesankan oleh guru sebagai lingkungan belajarnya (Sudjana, 2001). Akibat pengajaran yang kurang efektif ini siswa sering kali tidak berhasil apabila dihadapkan pada situasi yang mengharuskan menerapkan pengetahuan yang didapatkan dari kegiatan belajar mengajar. Model pembelajaran, yang juga bisa disebut strategi pembelajaran, dapat diartikan sebagi pola umum perbuatan guru murid didalam perwujudan kegiatan belajar mengajar dengan strategi yang lain (Cony, 1980). Bebarapa hal yang berpengaruh antara lain tujuan pembelajaran, siswa, materi yang diajarkan, serta faktor-faktor lain yang menunjang pencapaian tujuan pembelajaran. Oleh karena itu, perlu dikembangkan proses pembelajaran sesuai dengan karakteristik materi pembelajaran, siswa, dan penunjang lainnya.

Arikunto (2017) mengutarakan bahwa pada dasarnya model pembelajaran merupakan bentuk pembelajaran yang tergambar dari awal sampai akhir yang disajikan secara khas oleh guru. Dengan kata lain, model pembelajaran merupakan bungkus atau bingkai dari penerapan suatu pendekatan, metode, dan teknik pembelajaran.

Dengan adanya berbagai masalah dalam pembelajaran, tentu diperlukan suatu cara untuk mengatasi problem tersebut, agar dalam pembelajaran tidak muncul masalah, paling tidak masalah tersebut terkurangi. Untuk mengatasi berbagai problematika dalam pelaksanaan pembelajaran, tentu diperlukan modelmodel pembelajaran yang dipandang mampu mengatasi kesulitan guru melaksanakan tugas mengajar dan juga kesulitan belajar siswa (Arikunto:39). Dengan menggunakan model pembelajaran yang sesuai, maka akan menimbulkan semangat dan perasaan senang pada siswa untuk melakukan aktifitas belajar. Dan tentunya akan berpengaruh pada kualitas proses belajar mengajar di sekolah (Berowijayana, 2017).

Berdasarkan uraian di atas, maka penulis tertarik untuk melakukan penelitian dengan judul "Penerapan Model Pembelajaran Ekspositori untuk Meningkatkan Hasil Belajar Mekanika Teknik Siswa Kelas X DPIB 1 SMK Negeri 1 Blitar pada Semester 2 Tahun Pelajaran 2017/2018" Masalah yang akan dicari penyelesaiannya dalam penelitian ini dirumuskan sebagai berikut: (1) bagaimana penerapan model pembelajaran ekspositori untuk meningkatkan hasil belajar mekanika teknik siswa kelas X DPIB 1 SMK Negeri 1 Blitar pada semester 2 tahun pelajaran 2017/2018, (2) apakah model pembelajaran ekspositori efektif digunakan untuk meningkatkan hasil belajar mekanika teknik siswa kelas X DPIB 1 SMK Negeri 1 Blitar pada Semester 2 Tahun Pelajaran 2017/2018

Sedangkan tujuan yang ingin dicapai dalam penelitian ini yaitu: (1) mendeskripsikan penerapan model pembelajaran ekspositori untuk meningkatkan hasil pembelajaran mekanika teknik siswa kelas X DPIB 1 SMK Negeri 1 Blitar pada semester 2 tahun pelajaran 2017/2018 pada materi konstruksi rangka batang, 
dan (2) meningkatkan hasil belajar mekanika teknik siswa kelas X DPIB 1 SMK Negeri 1 Blitar pada semester 2 tahun pelajaran 2017/2018 pada materi konstruksi rangka batang melalui model pembelajaran ekspositori.

Penelitian ini diharapkan dapat memberikan manfaat antara lain berupa: (1) bagi peneliti, untuk mengetahui sejauh mana pengaruh penggunaan metode ekspositori terhadap hasil belajar siswa dan hasil penelitian ini sebagai sumber informasi serta sebagai referensi untuk mengadakan penelitian selanjutnya oleh peneliti yang bersangkutan maupun rekan guru yang lain, (2) bagi siswa, penelitian ini bisa digunakan sebagai salah satu sarana untuk meningkatkan pemahaman, kemampuan berfikir, motivasi, dan efektifitas, serta produktifitas pembelajaran, sehingga proses pembelajaran lebih bermakna dan hasil belajar lebih baik, (3) bagi guru, penelitian ini diharapkan bisa digunakan untuk mengetahui langkah-langkah yang harus disiapkan dalam menerapkan model pembelajaran ekspositori, dan sebagai tambahan wawasan dalam melaksanakan pembelajaran. Pelajaran mekanika teknik dalam Kurikulum 2013 yang direvisi masuk pada kelompok pelajaran C2 Dasar Program Keahlian dengan jumlah jam pelajaran 108 jam @ 45 menit (Silabus C2 BKP \& DPIB 2018/2019 SMK Negeri 1 Blitar, 2018:3). Pelajaran ini merupakan dasar dari pelajaran-pelajaran produktif pada tingkat berikutnya, misalnya pelajaran Konstruksi Jalan dan Jembatan, Kontruksi dan Utilitas Gedung, dan pelajaran yang lain-lain (Hosnan, 2016).

Langkah-langkah model pembelajaran ekspositori (Arikunto:37) sebagai berikut: (1) Persiapan (Preparation), (2) Penyajian (Presentation), (3) Korelasi (Correlation), (4) Menyimpulkan (Generalization), (5) Mengaplikasikan (Application). Melalui model pembelajaran ini, tidak hanya sekedar mengerjakan tugas atau serangkain test sebagai formalitas pembelajaran, namun diharapkan siswa memiliki pengamalaman pembelajaran yang lebih bermakna, terutama dalam mengerjakan tugas yang terkait dengan pelajaran mekanika teknik khususnya materi konstruksi rangka batang.

\section{METODE}

Penelitian tindakan kelas ini, dilaksanakan dalam 2 siklus pada kelas $\mathrm{X}$ DPB 1 SMK Negeri 1 Blitar dengan menerapkan model pembelajaran ekspositori. Tiap-tiap siklus dilaksanakan 2 kali pertemuan. Dalam penelitian ini menggunakan subyek peneliti selaku guru mekanika teknik kelas X DPB 1 SMK Negeri 1 Blitar beserta seluruh siswa di kelas tersebut yang berjumlah 36 siswa, terdiri dari 24 siswa laki-laki dan 6 siswa perempuan. Rancangan Penelitian Tindakan Kelas (PTK) model Kemmis dan Mc Taggart. Satu kali siklus terdiri dari: planning (perencanaan), acting (tindakan), observing (pengobservasian), dan reflekting (perefleksian). Hasil dari perefleksian ini selanjutnya digunakan untuk memperbaiki perencanaan (revise plan) pertemuan berikutnya (Kemmis \& MC.Taggart: 1990 dalam Akbar: 2010).

Penelitian ini menggunakan beberapa instrumen untuk menggambarkan proses dan hasil belajar siswa meliputi lembar test, lembar tugas, dan lembar observasi aktivitas guru. Teknik analisis data pada penelitian ini deskriptif secara kualitatif. Data aktivitas guru dari hasil kegiatan observasi dianalisis menggunakan teknik persentase sebagai berikut:

$$
\text { Nilai Rata-rata }=\frac{\text { Perolehan skor }}{\text { Jumlah skor maksimum }} \times 100 \%
$$


Kriteria ketuntasan atau keberhasilan tindakan ditentukan sebagai berikut.

$$
\begin{array}{ll}
85 \%<\mathrm{P} \leq 100 \% & =\text { Sangat Baik (A) } \\
70 \%<\mathrm{P} \leq 84 \% & =\text { Baik }(\mathrm{B}) \\
55 \%<\mathrm{P} \leq 69 \% & =\text { Cukup }(\mathrm{C}) \\
40 \%<\mathrm{P} \leq 54 \% & =\text { Kurang Baik (D) } \\
0 \%<\mathrm{P} \leq 39 \% & =\text { Sangat Kurang (E) }
\end{array}
$$

Pembelajaran dikatakan berhasil ( tuntas) jika sekurang-kurangnya 85\% siswa dalam satu kelas telah mencapai nilai KKM yaitu $>75$. Selain itu mengacu pada Panduan Penilaian Hasil Belajar pada Sekolah Menengah Kejuruan yang dikeluarkan Kemendikbud tahun 2017 maka kategori penilaian dengan nilai KKM 75 dan pembulatan angka kesatuan terdekat sebagai berikut:

$\begin{array}{ll}\text { Kurang dari } 75 & \text { : Kurang ( belum mencapai KKM } \\ 75 \text { s.d } 88 & \text { : Baik (mencapai KKM) } \\ 89 \text { s.d } 100 & \text { : Sangat baik (melampui KKM) }\end{array}$

\section{HASIL PENELITIAN}

1. Paparan Data Prasiklus

Penilaian awal yang digunakan adalah penilaian dari materi sebelumnya yaitu redoks. Hasil akhir nilai ketrampilan menunjukan hanya 19 siswa ( 53\%) dan hasil nilai pengetahuan menunjukan hanya 13 siswa ( $36 \%$ ) yang mencapai nilai KKM. Berarti belum memenuhi syarat ketuntasan belajar secara klasikal. Berdasarkan hasil observasi awal kelas X DPIB 1 SMK Negeri 1 Blitar tersebut peneliti berkesimpulan hasil pembelajaran mekanika teknik masih kurang, sehingga memenuhi syarat untuk dijadikan subyek penelitian tindakan kelas dengan model pembelajaran ekspositori.

\section{Paparan Data Siklus 1}

Kegiatan dalam siklus 1 terdiri dari perencanaan, tindakan, pengobservasian, dan refleksi yang dilakukan dalam dua kali pertemuan. Pada tahap perencanaan dilakukan penyiapan seluruh perangkat pembelajaran untuk menerapkan model ekspositori berupa RPP dan instrumen lain untuk pengambilan data hasil belajar siswa, yang terdiri dari lembar observasi kegiatan guru, kisi-kisi soal, soal, lembar penilaian pengetahuan maupun keterampilan.

Pada siklus 1 ada 2 pertemuan, pada pertemuan 1 siklus 1 guru mengawali pembelajaran dengan melakukan apersepsi berupa tanya jawab tentang materi redoks. Sebelumnya guru menyampaikan tujuan pembelajaran, pemberian stimulasi (rangsangan) berupa paparan suatu permasalahan terkait konsep konstruksi rangka batang dan aplikasinya dalam kehidupan sehari-hari dalam bentuk power poin. Kemudian dilanjutkan penyampaian materi pengantar konstruksi rangka batang yang disusun sesuai langkah-langkah model pembelajaran ekspositori. Lalu dilanjutkan diskusi kelas, dimana masing-masing kelompok menyampaikan hasil diskusi bergantian. Di akhir diskusi kelompok guru mengajak siswa bersama-sama membuat kesimpulan tentang tujuan pembelajaran hari itu. Di akhir pertemuan dilakukan uji pemahaman materi pembelajaran atau hasil belajar siswa lewat ujian formatif (post tes). 
Pada pertemuan 2 siklus 1 guru mengawali pembelajaran dengan melakukan apersepsi berupa tanya jawab tentang materi konstruksi rangka batang, yaitu bagian menghitung besarnya gaya batang dengan metode Cremona. Sebelumnya diawali oleh guru dengan menyampaikan tujuan pembelajaran, pemberian stimulasi berupa paparan suatu permasalahan terkait menghitung rangka batang cara Cremona dan aplikasinya dalam kehidupan sehari-hari dengan mendemonstrasikan langkah-langkah penyelesaian metode Cremona.

Siswa memperhatikan kegiatan guru dan mengikuti menggambar Cremona. Di akhir pertemuan dilakukan uji pemahaman dengan mendiskusikan kelebihan dan kekurangan metode Cremona tersebut, serta membahas bagian-bagian yang belum dipahami secar bersama-sama

Kemudian guru memberikan tugas untuk dikerjakan di luar kelas (sebagian di rumah dan sebagain bersama di sekolah/di luar jam pelajaran mekanika teknik). Tugas ini dikumpulkan pada hari kedua setelah jam/hari pelajaran mekanika teknik. Tujuan pengambilan waktu ini adalah: siswa bisa mencoba secara mandiri pada malam harinya, kemudian mendiskusikan dengan teman-temannya dan guru apa bila ada bagian yang belum bisa dikuasai, dan menyelesaikan pada malam harinya, kemudian besok pagi dikumpulkan untuk dikoreksi oleh guru.

Observasi dilakukan terhadap aktivitas guru untuk mengetahui keterlaksanakan penerapan model pembelajaran ekspositori secara tepat, baik, dan lancar yang dilakukan oleh teman sejawat sebagai observer. Hasil observasi aktivitas guru yang dilakukan oleh teman sejawat, dengan prosentase pertemuan 1 sebesar $73 \%$ dan pertemuan 2 sebesar $78 \%$, sehingga jika dirata-rata antara pertemuan pertama dan kedua sebesar $76,5 \%$. Angka ini menjunjukkan sudah termasuk kategori baik (B), namun masih belum optimal.

Observasi terhadap hasil belajar siswa dilakukan dengan pemberian tes yang dilaksanakan pada akhir pertemuan. Berdasarkan data nilai pengetahunan rata-rata hasil tes pertemuan 1 dan pertemuan 2 menunjukan $39 \%$ kategori penilaian kurang, 50\% kategori penilaian baik, dan 11\% kategori penilaian sangat baik. Sehingga masih $61 \%$ siswa mencapai nilai KKM. Sedangkan data nilai keterampilan rata-rata hasil tes pertemuan 1 dan pertemuan 2 menunjukan $22 \%$ kategori penilaian kurang, 11\% kategori penilaian baik, dan 67\% kategori penilaian sangat baik. Disini masih 78\% siswa mencapai nilai KKM.

Tahap akhir dari suatu siklus 1 adalah perefleksian, yaitu meliputi kegiatan seperti berikut (1) data hasil hasil belajar siswa setelah proses pembelajaran dengan model ekspositori, baik yang berupa pengetahuan maupun keterampilan, (2) data hasil observasi guru dalam proses pembelajaran dengan model pembelajaran ekspositori, (3) melakukan analisis terhadap temuan-temuan yang berkaitan dengan hambatan, kekurangan, kelebihan selama pembelajaran berlangsung, baik yang dilakukan siswa maupun guru, (4) melakukan refleksi dari hasil analisis terhadap pelaksanaan tindakan.

\section{Paparan Data Sikus 2}

Kegiatan dalam siklus 2 terdiri dari perencanaan, tindakan, pengobservasian, dan refleksi yang dilakukan dalam dua kali pertemuan. Pada tahap perencanaan dilakukan penyiapan seluruh perangkat pembelajaran mekanika teknik, serta instrumen untuk pengambilan data hasil belajar siswa dalam siklus 2 yang terdiri 
dari lembar observasi kegiatan guru, kisi-kisi soal, soal, lembar penilaian keterampilan, dan catatan keterangan lainnya.

Pada siklus 2 ada 2 pertemuan. Pada pertemuan 1 siklus 2 guru mengawali pembelajaran dengan melakukan apersepsi berupa tanya jawab tentang materi konstruksi rangka batang yang merupakan prasyarat untuk mempelajari materi berikutnya. Guru menyampaikan tujuan pembelajaran, pemberian stimulasi (rangsangan) berupa paparan suatu permasalahan terkait konsep konstruksi rangka batang dan aplikasinya dalam kehidupan sehari-hari dalam bentuk power point. Kemudian dilanjutkan menjelaskan materi sesuai RPP dan program semester tenatang konstruksi rangka batang dengan metode Culman.

Pada pertemuan ini guru mengawali pembelajaran dengan melakukan apersepsi berupa tanya jawab tentang materi konstruksi rangka batang, yaitu bagian menghitung besarnya gaya batang dengan metode Culman. Sebelumnya diawali oleh guru dengan menyampaikan tujuan pembelajaran, pemberian stimulasi berupa paparan suatu permasalahan terkait menghitung rangka batang cara Cremona kelebihan dan kekurangannya, dan dijelaskan mengapa diperlukan atau ditempuh cara Culman. Gambaran sederhana, pada cara Cremona dihitung semua gaya batang secara berurutan, sehingga apabila menghendaki atau ingin mengetahui besarnya gaya batang di bagian tengah, harus dikerjakan dari bagian tepi hingga mencapai bagian yang diinginkan, sehingga memakan waktu yang relatif lama. Dengan cara Culman, bisa langsung mengitung besarnya gaya batang tertentu yang diinginkan (tidak perlu dari awal), sehingga wakunya relatif lebih cepat.

Dalam kegiatan ini, siswa memperhatikan kegiatan guru dan mengikuti menggambar Culman. Di akhir pertemuan dilakukan uji pemahaman dengan mendiskusikan kelebihan dan kekurangan metode Culman tersebut, serta membahas bagian-bagian yang belum dipahami secar bersama-sama kemudian guru memberikan tugas untuk dikerjakan di luar kelas, sebagian dikerjakan di rumah dan sebagian dikerjakan bersama-sama siswa lain (dalam satu kelas) di sekolah (di luar jam pelajaran mekanika teknik). Tugas ini dikumpulkan pada hari kedua setelah jam/hari pelajaran mekanika teknik. Tujuan pengambilan waktu ini adalah: siswa bisa mencoba mengerjakan secara mandiri pada malam harinya, kemudian mendiskusikan dengan teman-temannya dan guru apa bila ada bagian yang belum dikuasai, dan menyelesaikan pada malam harinya, kemudian besok pagi dikumpulkan untuk dikoreksi oleh guru.

Yang membedakan dengan cara konvensional pada umumnya adalah dalam hal pemberian bentuk tugas keterampilan. Tugas yang diberikan setiap anak dibedakan mengenai besarnya beban yang bekerja pada konstruksi kuda-kuda tergantung nomor presensi masing-masing. Meskipun cara mengerjakannya setiap anak sama, namun hasil perhitungan setiap anak besarnya berbeda-beda, tergantung nomor presensi siswa, dengan demikian kecil peluangnya seorang siswa hanya mencontoh pekerjaan milik temannya.

Dalam proses koreksi hasil pekerjaan siswa, guru pengajar menyiapkan kunci jawaban dengan program MS Excell yang sederhana, untuk mengetahui besarnya masing-masing gaya batang jawaban siswa. Saat melakukan koreksi tugas keterampilan, dalam lembar kerja tugas siswa tersebut apabila ada bagian yang salah ditunjukkan, misalnya dengan tanda ballpoin warna merah yang selanjutnya akan dibahas pada pertemuan berikutnya. Pada pembahasan ini, diharapkan siswa 
mengetahui kekurangannya, sehingga tidak akan terjadi lagi kesalahan yang sama pada materi bahasan berikutnya.

Observasi dilakukan terhadap aktivitas guru untuk mengetahui keterlaksanaan penerapan model pembelajaran ekspositori di kelas secara tepat, baik, dan lancar. Observasi dilakukan oleh guru lain sesama guru teknik bangunan sebagai observer. Hasil observasi aktivitas guru yang dilakukan oleh teman sejawat yang merupakan rata-rata pertemuan 1 dan 2 . Hasil obeservasi pada siklus 2 pertemuan pertama, nilai rata-rata observasi meningkat menjadi $83 \%$ dan pada pertemuan kedua nilai rata-rata observasi mencapai $88 \%$, sehingga didapat nilai rata-rata dari nilai pertemuan pertama dan kedua mencapai $86,5 \%$ yang sudah tergolong baik/B. Berdasarkan nilai rata-rata pada siklus 2 sudah ada peningkatan yang cukup signifikan dibandingkan pada siklus 1 (yang nilainya 76,5\%).

Pada akhir siklus 2 dilakukan perefleksian untuk menentukan apakah siklus ini sudah berhasil atau belum. Kegiatan dalam satu siklus dikatakan berhasil jika 85\% siswa telah memperoleh nilai KKM dari aspek pengetahuan maupun ketrampilan. Pada aspek pengetahuan sebanyak 89\% siswa kelas X DPIB 1 SMK Negeri 1 Blitar yang telah mencapai nilai minimal KKM, sedangkan aspek ketrampilan sebanyak 94\%. Karena jumlah siswa yang mencapai nilai minimal KKM pada aspek pengetahuan dan ketrampilan lebih dari 85\%, maka pada siklus 2 pembelajaran dengan model pembelajaran ekspositori dikatakan berhasil dan tidak perlu dilanjutkan ke siklus III.

\section{PEMBAHASAN}

Dari hasil observasi terhadap kegiatan guru dalam penerapan model pembelajaran ekspositori pada siswa kelas X DPIB 1 SMK Negeri 1 Blitar dari siklus 1 ke siklus 2 menunjukan guru dapat menerapkan model pembelajaran dengan baik. Pada siklus 1 dengan rata-rata keberhasilan 76,5\%. Sedangkan pada siklus 2 menghasilkan peningkatan sebesar $10,0 \%$ dengan ditunjukan oleh ratarata keberhasilan sebesar $86,5 \%$ (sangat baik). Penilaian hasil belajar siswa pada pelajaran mekanika teknik meliputi aspek keterampilan dan pengetahuan. Peningkatan hasil belajar siswa kelas X DPIB 1 SMK Negeri 1 Blitar aspek ketrampilan dari siklus 1 ke siklus 2 menunjukan adanya peningkatan jumlah siswa yang mencapai nilai minimal KKM sebesar 17\% (dari 78\% menjadi 94\%). Dan pada siklus 2 kategori penilaian terbagi menjadi 5,5\% kategori penilaian kurang, 19,8\% kategori penilaian baik, dan 75,0\% kategori penilaian sangat baik.

Peningkatan hasil belajar untuk aspek pengetahuan dari siklus 1 ke siklus 2 menunjukan adanya peningkatan jumlah siswa yang mencapai nilai minimal KKM sebesar 28\% (dari 61\% menjadi 89\%). Dan pada siklus 2 kategori penilaian terbagi $11 \%$ kategori penilaian kurang, 33\% kategori penilaian baik, dan 56\% kategori penilaian sangat baik. Dari hasil pembahasan di atas dapat disimpulkan bahwa hasil belajar siswa pada mata pelajaran mekanika teknik pada sub konstruksi rangka batang siswa kelas X DPIB SMK Negeri 1 Blitar dapat ditingkatkan dengan penerapan model pembelajaran ekspositori.

\section{KESIMPULAN}

Dari hasil pembahasan di atas maka dapat disimpulkan: (1) model ekspositori dapat diterapkan pada pembelajaran mekanika teknik pada sub bab konstruksi rangka batang, (2) hasil belajar siswa pada matapelajaran mekanika 
teknik kelas X DPIB 1 SMK Negeri 1 Blitar dapat ditingkatkan melalui penerapan model pembelajaran ekspositori.

\section{SARAN}

Dari hasil penelitian ini kami menyarankan: (1) bagi peneliti, agar proses pembelajaran dengan model pembelajaran ekspositori bisa berjalan baik dan lancar diperlukan pemaparan masalah, digunakan bahasa yang mudiah dipahami, intonasi yang sesuai dan menarik, menjaga perhatian dan kontak mata dengan siswa, agar tidak ada kesalahan dalam persepsi dan arti dalam penentuan maksud permasalahan, sehingga siswa mudah menyelesaikan persoalan mekanika teknik, (2) bagi siswa, dalam penyelesaian soal-soal mekanika teknik dengan metode ekspositori, selain guru yang aktif, siswa juga harus aktif, baik saat penyampaian materi oleh guru, mengadakan tanya jawab dan penyimpulan materi pelajaran, dan terutama dalam menyelesaikan tugas yang diberikan guru, termasuk pembahasan hasil tugas siswa oleh guru dan siswa-siswa lain, (3) bagi rekan guru yang akan melakukan penelitian dengan model pembelajaran ekspositori, agar berjalan dengan lancar dan baik, perlu disiapkan dengan baik seluruh perangkat dan instrumen yang diperlukan.

\section{DAFTAR RUJUKAN}

Akbar, S. 2010. Penelitian Tindakan Kelas Filosofi, Metodologi \& Implementasi. Yoyakarta: Cipta Media Aksara.

Akbar, S. dan Luluk Faridatuz Z. 2010. Prosedur Penyusunan Laporan dan Artikel Hasil Penelitian Tindakan Kelas. Yogyakarta: Cipta Media, Cetakaan II.

Arikunto, A Suharsimi. 2010. Prosedur Penelitian - Suatu Pendekatan Praktik. Jalarta: PT Rineka Cipta, Cetakan Ke empat belas

Arikunto, A Suharsimi, 2017. Penelitian Tindakan Kelas. Jakarta: PT Bumi Aksara, Cetakan Kedua

Arikunto, A Suharsimi. 2013. Dasar-dasar Evaluasi Pendidikan Edisi 2. Jakarta: PT Bumi Aksara, Cetakan Ketiga

Berowiyana. 2017. Mekanika Teknik - Konstruksi Rangka Batang. Blitar: KPRI STM Negeri Blitar

Jumanta Hamdayama. 2014. Model dan Metode Pembelajaran Kreatif dan Berkarakter. Jakarta: Ghalia Indonesia.

M. Hosnan. 2016. Pendekatan Saintifik dan Konstekstual dalam Pembelajaran Abad 21. Jakarta: Ghalia Indonesia, Cetakan Ketiga. 